\title{
Plant diversity and composition compensate for negative effects of urbanization on foraging bumble bees
}

\author{
Marietta HÜLSMANN ${ }^{1}$, Henrik von WeHRDEN ${ }^{1,2,3}$, Alexandra-Maria KLEIN ${ }^{1,4}$, \\ Sara Diana LEONHARDT ${ }^{5}$ \\ ${ }^{1}$ Institute of Ecology, Faculty of Sustainability, Leuphana University Lüneburg, Scharnhorststr. 1, 21335, Lüneburg, \\ Germany \\ ${ }^{2}$ Centre of Methods, Leuphana University Lüneburg, Scharnhorststr. 1, 21335, Lüneburg, Germany \\ ${ }^{3}$ Research Institute of Wildlife Ecology, Savoyen Strasse 1, Vienna 1160, Austria \\ ${ }^{4}$ Chair of Nature Conservation and Landscape Ecology, Institute of Earth and Environmental Sciences, University of \\ Freiburg, 79106, Freiburg, Germany \\ ${ }^{5}$ Department of Animal Ecology and Tropical Biology, University of Würzburg, 97074, Würzburg, Germany
}

Received 6 October 2014 - Revised 21 February 2015 - Accepted 18 March 2015

\begin{abstract}
Bumble bees play an important role as pollinators of many crop plants and wild flowers. As in many wild bees, their abundance and diversity have declined in recent years, which may threaten the stability of pollination services. The observed decline is often linked with the loss or alteration of natural habitat, e.g., through urbanization, the conversion of natural habitat into largely sealed areas (concrete) inhabited by humans. The effects of urbanization on bumble bees remain as yet controversial with both positive and negative effects reported. We investigated how habitat isolation through increasing areas of concrete, as well as the diversity, abundance, and community composition of floral resources, determine bumble bee abundance and diversity in cities. We found plant species diversity and abundance to be more important than the amount of concrete in driving the abundance and species richness of common bumble bees in a German city. Moreover, plant species composition, i.e., the presence of specific plant species and families (e.g., Fabaceae), played a prominent role. In particular, flower-rich parks and gardens can offer a continuous food supply for bumble bees and attract bumble bee foragers even to isolated patches in the city center.
\end{abstract}

bee decline / habitat fragmentation / Hymenoptera / pollination / urban landscape

\section{INTRODUCTION}

Globally, the decline of pollinators and potential loss of pollination services was estimated to result in an annual economic deficit of 153 billion EUR of the agricultural sector due

Electronic supplementary material The online version of this article (doi:10.1007/s13592-015-0366-x) contains supplementary material, which is available to authorized users.

Corresponding author: S. Leonhardt, sara.leonhardt@uni-wuerzburg.deD. Leonhardt, sara.leonhardt@uni-wuerzburg.de

Manuscript editor: James Nieh to failure of fruit production in animalpollinator-dependent crop plants (Gallai et al. 2009). For Europe alone, the annual economic benefit of bee pollination exceeds 14 billion EUR (Leonhardt et al. 2013). Primitively eusocial bumble bees (Apidae: Bombus Latreille) are particularly important wild bee pollinators of crops and wild flowers in most temperate countries (Fussell and Corbet 1992) because single colonies comprise relatively high forager numbers and foragers show high individual flower constancy (Heinrich 1976; Heinrich et al. 1977; Kleijn and Raemakers 2008), start foraging early, and forage for most of the flowering season (Goulson 2010). 
Although several bumble bee species are still common (but see Lye et al. 2012), the occurrence of a general bumble bee decline has been debated for 60 years (Fitzpatrick et al. 2007; Goulson et al. 2008b; Connop et al. 2010). One frequently discussed cause for the observed decline is habitat alteration and loss, especially through intensified farming (Fischer and Lindenmayer 2007; Goulson et al. 2008b; Bommarco et al. 2010; Pellissier et al. 2013) and increasing urbanization (Ahrné et al. 2009; Kearns and Oliveras 2009; Bates et al. 2011; Geslin et al. 2013). In many European countries, up to $80 \%$ of the population lives in cities with urbanization further increasing (Antrop 2004). Increasing urbanization is generally associated with an increase in concrete and a decrease in animal and plant diversity (Geslin et al. 2013; Martins et al. 2013; Williams and Winfree 2013).

However, cities can also provide new (foraging) habitat for animals (Paker et al. 2014), and some studies revealed gardens, parks, and meadows as islands for insects (Gaston et al. 2005a; Matteson et al. 2008; Ahrné et al. 2009; Garbuzov et al. 2013).

Nevertheless, in Stockholm (Sweden), bumble bee abundance decreased with increasing housing density (Ahrné et al. 2009). Cities comprise different types of (urban) green areas, e.g., parks, gardens, flower strips, patches, etc., which can differentially affect the abundance and species richness of bumble bees (Pellissier et al. 2013). Particularly, gardens provide a variety of flowering plant species that are frequently visited by bumble bees (Eremeeva and Sushchev 2005; Nielsen et al. 2008; Sikora and Kelm 2012) and may compensate for the negative effect of concrete. How these two factors interact has, however, not yet been determined. Moreover, the quality (i.e., composition) of floral resources at specific urban green areas, such as gardens, varies and plays an important role in determining bee abundance and community composition (Tommasi et al. 2004), but this has also not been investigated in detail for bumble bees visiting flowering plants in urban areas. It is also unclear whether their flower visitation patterns, e.g., the degree of specialization of bumble bee-plant networks, in urban areas differ from patterns observed for (semi- )natural areas. One of the few studies that has analyzed the degree of specialization in flowervisiting bumble bees found the network to be rather generalized in semi-natural areas (median network specialization index $H_{2}{ }^{\prime}=0.33$ ) and that the degree of specialization did not change with the diversity of flowering plant species (Fründ et al. 2010).

All things considered, we still do not fully understand how different aspects of urbanization affect abundance, diversity, and flower visitation patterns or the degree of network specialization of bumble bees. Therefore, we investigated the distribution of bumble bees in the city of Lüneburg (Germany) in relation to urbanization (which we define as the amount of concrete that increases towards the city center and correlates with flowering plant abundance), plant diversity, and plant community composition. We hypothesize that the abundance and species richness of bumble bees is (1) negatively correlated with increasing urbanization, but (2) positively correlated with the abundance and diversity of floral resources in the city. We further hypothesize that bumble bee abundance and richness respond more to plant composition than to urbanization per se and that the degree of specialization of the urban bumble bee-plant network is similar to networks recorded for (semi-)natural areas.

\section{MATERIALS AND METHODS}

\subsection{Study sites}

The study was conducted in Lüneburg from beginning of April to the beginning of October 2013. Lüneburg is a small provincial town close to the metropole region of Hamburg in the north of Germany (Lower Saxony) with about 70,000 inhabitants. Beyond the city boundary, there are several crop fields dominated by arable fields, pastures, and a high density of small villages.

Fifteen study plots (comprising an area of $50 \mathrm{~m}$ in diameter) were chosen within the city boundary with around $1 \mathrm{~km}$ in between two adjacent study plots: five in the suburbs, five in the city center, and five between them (here defined as urban area). The main criteria for our site selection were the distance from the central point, the distribution over the city area (including 
central urban, suburban, and periphery areas), and the abundance and richness of flowering plant species at a site.

The "Hauptschule Stadtmitte" was chosen as the central point of Lüneburg (as indicated by Google Earth: latitude $53.246407^{\circ} \mathrm{N} /$ longitude $10.411525^{\circ}$ $\mathrm{N})$. For each site, the distance from the central point was measured with the freely accessible ruler function in Google Earth (Figure S1, Table SI).

Additionally, a $500 \mathrm{~m}$ radius $\left(785,398.16 \mathrm{~m}^{2}\right)$ was drawn around the central point of each $50 \mathrm{~m}$ study site using Google Earth and the Keyhole Markup Language (KML) Circle Generator for Google Earth to assess the degree of urbanization around the study site. The circled area was then divided into 16 fragments of same size $\left(49,087 \mathrm{~m}^{2}\right)$, and the area of trees, meadows, gardens, concrete, farmland, and water (see Table SIII for a detailed description of coverage types) within each fragment was visually assessed at a magnitude of $10 \%$ steps in Google Earth. The percentage amounts of each coverage type were summed up for each circle (Table SI).

The proportion of concrete within the $500 \mathrm{~m}$ radius decreased significantly with increasing distance from the city central point (Pearson's correlation, $r=-0.88, P<0.001)$. Distance from the city central point was therefore used as a measure for decreasing urbanization.

Before we started the monthly monitoring, all flowering plants at each study site were identified to species level (or genus level if the species could not be clearly identified) using taxonomic keys (Jäger 2011; Schmeil and Fitschen 2011). Identification of flowering plants was performed directly at the study plots before the bumble bee monitoring started.

\subsection{Monitoring}

Every study site was surveyed once per month between $10 \mathrm{AM}$ and $7 \mathrm{PM}$ on nonrainy days with temperatures above $15{ }^{\circ} \mathrm{C}$ and an average wind speed below $2.5 \mathrm{~m} / \mathrm{s}$. Site visitation was repeated in intervals of 28 days, and visitation order was randomized to ensure that every study site was surveyed in the morning, afternoon, and early evening. Overall, we performed 105 surveys.

Following Braun-Blanquet (1994), we counted the number of flowering trees, bushes, and herbal plants (within the $25 \mathrm{~m}$ radius). To classify all flowering plant species according to their flowering area provided in total per site (rendering single flowering plants and large tree species comparable), a blooming product $\left(B_{\mathrm{p}}\right)$ was defined for each plant species:

$$
B_{\mathrm{p}}=N_{\mathrm{p}} \times b_{\mathrm{a}} \times N_{\mathrm{b}}
$$

where $b_{\text {a }}$ represents the area of a single blossom [measured in diameter $(\mathrm{cm})], N_{\mathrm{b}}$ the average number of blossoms per plant species, and $N_{\mathrm{p}}$ the number of individuals per plant species per site. Data on blossom area and estimated number of blossoms per plant were obtained from Schmeil and Fitschen (2011), Rothmaler (Jäger 2011), and "Illustrierte Flora von Mitteleuropa" (Hegi et al. 1995). Thus, the blooming product represents a measure for the flowering area, which likely attracts foragers from a distance and potentially, but not necessarily, correlates with the amount of floral resources.

The entire study site (for a detailed description of each site, see SI and SII) was examined for $30 \mathrm{~min}$ for the presence of bumble bees, which was sufficient to observe small flowering herbal plant species for approximately $5 \mathrm{~s}$ and trees for up to $3 \mathrm{~min}$. We always started at the same point at a site and randomly crossed meadows and lawns. This way of monitoring was performed for all sites except for gardens with beds where we walked from flowering plant to flowering plant. All bumble bees observed on flowers or in flight were counted and classified into one of six species groups according to the identification keys of Prŷs-Jones and Corbet (2011), Hagen et al. (2003), and Edwards and Jenner (2009) and listed under the name of the most common species in this group (see Table SIV). If the species group could not be clearly identified on the spot, bumble bees were caught with a plastic tube or an insect net and identified using a magnifier. We used the species group categories because some rare species (e.g., Bombus magnus Vogt and Bombus cryptarum Fabricius) and several common species (e.g., Bombus terrestris Linnaeus) could not be distinguished in the field using a visual taxonomic approach (Lye et al. 2012). Queens and workers were distinguished by their size and the season of observation. Drones were identified based on their clypeus setae (Edwards and Jenner 2009).

On large trees that can grow up to $30 \mathrm{~m}$ (e.g., Tilia platyphyllos Scop. (Malvaceae) (Jäger 2011)), only 
those bumble bees where counted that could be seen from the ground.

Note that, we may have counted the same individual more than once, as we did not capture bees.

\subsection{Statistical analysis}

We analyzed species richness and abundance using generalized linear mixed effect models (GLMM), with a Poisson error distribution and sites and time included as random effects. Individual species were modeled with a binomial error distribution. We used an information theoretic approach for model selection to identify models that best explained bumble bee species richness, abundance, and presence of individual species and to differentiate between the effects of variables related to urbanization and plants. We constructed six alternative candidate models arising from specific hypothesis derived combinations of the four groups of fixed variables (plant diversity $=P$, blooming product $=B$, vegetation community patterns $=V$, habitat ordination $=H$ ) and the null model. Plant diversity $(P)$ was entered as species richness. Vegetation community patterns $(V)$ included the distribution of all plant species and were analyzed with a detrended correspondence analysis (DCA, see Figure S2) using loadings on the first axis as a predictor for the main vegetation community dynamics based on all vegetation surveys. Habitat data $(H)$ comprised the percentage amounts of each vegetation type (summed up for each circle), which was transformed via a principal component analysis (PCA, see Figure S3) and correlated negatively with distance from the city central point (GLMM: model estimate $\pm \mathrm{SD}$ : $-0.64 \pm 0.31$, $P=0.04$ ). We used the loadings on the first axis as a predictor for the most important habitat dynamics.

Tested hypotheses were $B+V, B+H, V+H$, $D+B+H, B+V+H$, and $D+B+V+H$ (i.e., models with each of these variable combinations were tested against each other). Predictors within the GLMM were tested for collinearity, but no redundant predictors were detected within our predictor combinations. We used the $\mathrm{R}$ package "AICmodavg" to rank the candidate models, based on Akaike's information criterion corrected (AICc) values to account for small-sample bias.

The quantitative network-level specialization index $H_{2}{ }^{\prime}$ (Blüthgen et al. 2006) was applied to characterize the degree of floral specialization across bumble bee species groups with regard to plant species visited. $\mathrm{H}_{2}{ }^{\prime}$ ranges between 0 (bumble bees of all species groups visit similar plant species) and 1 (each species group visits a specific set of plant species).

\section{RESULTS}

In total, 699 bumble bees were counted over the sampling period, belonging to the species groups of Bombus pascuorum (247), B. terrestris (208), Bombus lapidarius (128), Bombus hypnorum (44), Bombus hortorum (37), and Bombus pratorum (35) (Tables SII, SV, and SVI). Overall, 381 (54.5\%) bumble bees were recorded in the urban area, $208(29.8 \%)$ in the suburban area, and $110(15.7 \%)$ in the city center. The study sites with fewest bumble bees (fewer than 27) were all located in the city center (see Tables SII and SVI).

Most bumble bees and bumble bee species were recorded in August (210 bees in total). Most plant species were recorded in July (208) and June (171) (Tables SII, SV, and Figure 1). These plants were found at the "Kurpark" (146), Leuphana botanical garden (101), "Pferdeteich" (90), "Hasenburger Weg" (59), and the town hall garden (59) (Tables SII and SVI). All of these study plots were cultivated continuously with flowering plants by private or professional gardeners.

We recorded overall 255 different plant species over the study period (Table SI). Of these, 86 were visited by bumble bees (Figure 2). If ranked by blooming product (i.e., flowering area), the plant with largest flowering area was Malus domestica Borkh, which was visited by only two bumble bee queens in April (Table SII), while the most abundant flower in terms of numbers was Bellis perennis L. (Asteraceae Bercht and J. Presl), which was not visited by any bumble bees. Trifolium repens L. (Fabaceae Lindl.) was the plant species visited most in this study (Figure 2). Fabaceae (190 bumble bees), Lamiaceae L. (121), Rosaceae Juss. (84), Asteraceae (76), and Malvaceae Juss. (41) were the most frequently visited plant families (see also Table SII). Overall, plant diversity increased with increasing distance from the city central point (Spearman rank correlation: $r=0.35, P<0.001$ ).

Both bumble bee abundance and species richness were best described by models including all 


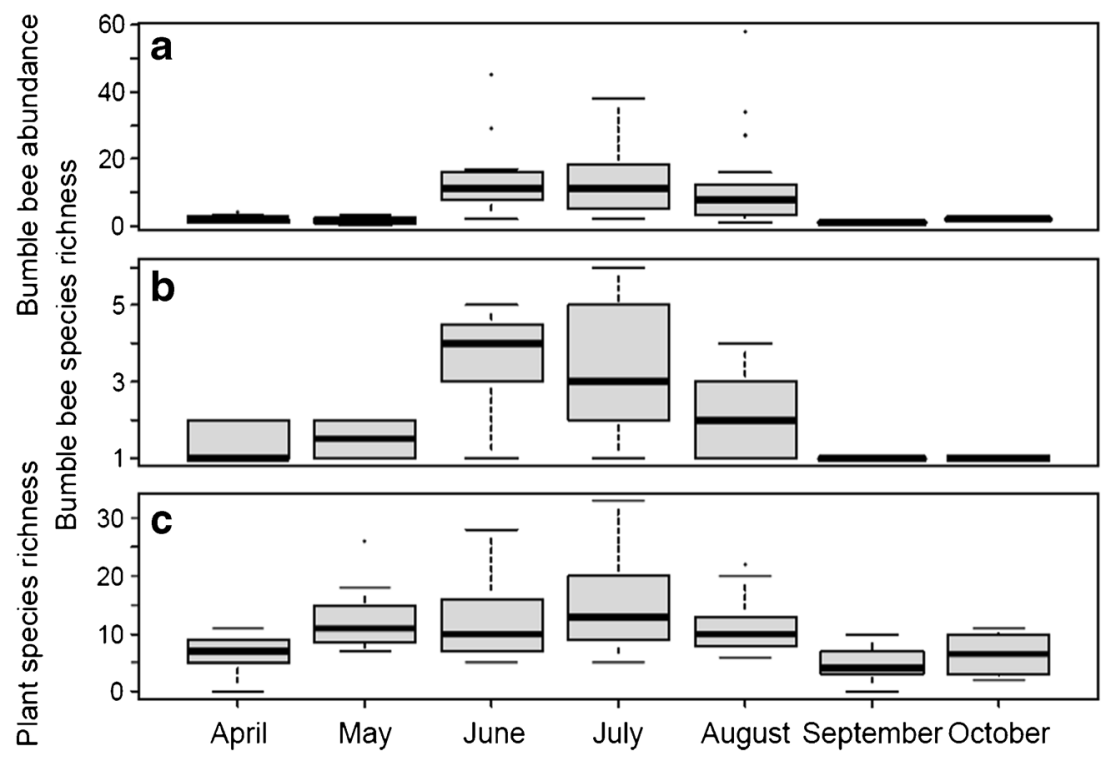

Figure 1. Changes in bumble bee abundance (a), species richness (b ), and plant species richness (c) across months.

parameters [i.e., plant diversity $(D)$, blooming product $(B)$, vegetation community patterns $(V)$, and habitat parameters $(H)]$ as was the abundance of all bumble bee species groups, except for B. pascuorum (Table I). However, the blooming product generally had the least effect on the total and species group abundance or number of bumble bee groups, while overall abundance and species richness both increased strongly with increasing plant diversity (Table II, Figure 3) and decreased slightly towards the city center (see negative correlation with habitat PCI coordinates (Table II), which increase towards the city central point (see "Materials and methods")).

All bumble bee species groups visited a broad spectrum of plant species and plant species overlapped between bumble bee species (Table SII, Figure 2). All bumble bee groups thus showed a generalized foraging behavior $\left(H_{2}{ }^{\prime}=0.42\right.$, Table SII, Figure 2). The highest number of plant species was visited by B. pascuorum (47 different plant species) and B. terrestris/lucorum (51 different plant species) (Table SII, Figure 2). The abundance of the latter was most strongly determined by plant diversity, while plant community composition had the strongest effect on the abundance of all other species groups (Table II).
Species abundance typically decreased towards the city center, except for B. pratorum (Table II).

\section{DISCUSSION}

Along an urbanization gradient in the German city of Lüneburg, plant species diversity and community composition strongly affected the species richness and abundance of foragers of six bumble bee groups, while the distance from the city center and hence an increasing amount of concrete (i.e., urbanization) had a comparatively weak effect. As plant species diversity decreased with decreasing distance from the city's central point, our results confirm a negative effect of urbanization on plant species diversity and thus bumble bees, which agrees with previous studies (Ahrné et al. 2009; Bates et al. 2011; Banaszak-Cibicka and Żmihorski 2012; Jha and Kremen 2013b; Aronson et al. 2014), but indicates that floral richness and composition, not urbanization per se, determine the presence of bumble bee foragers in small cities, such as Lüneburg.

Interestingly, most bumble bees were found at sites with intermediate urbanization (urban area), such as the Kurpark, the Leuphana campus, and the Pferdeteich. All of these sites were all highly 

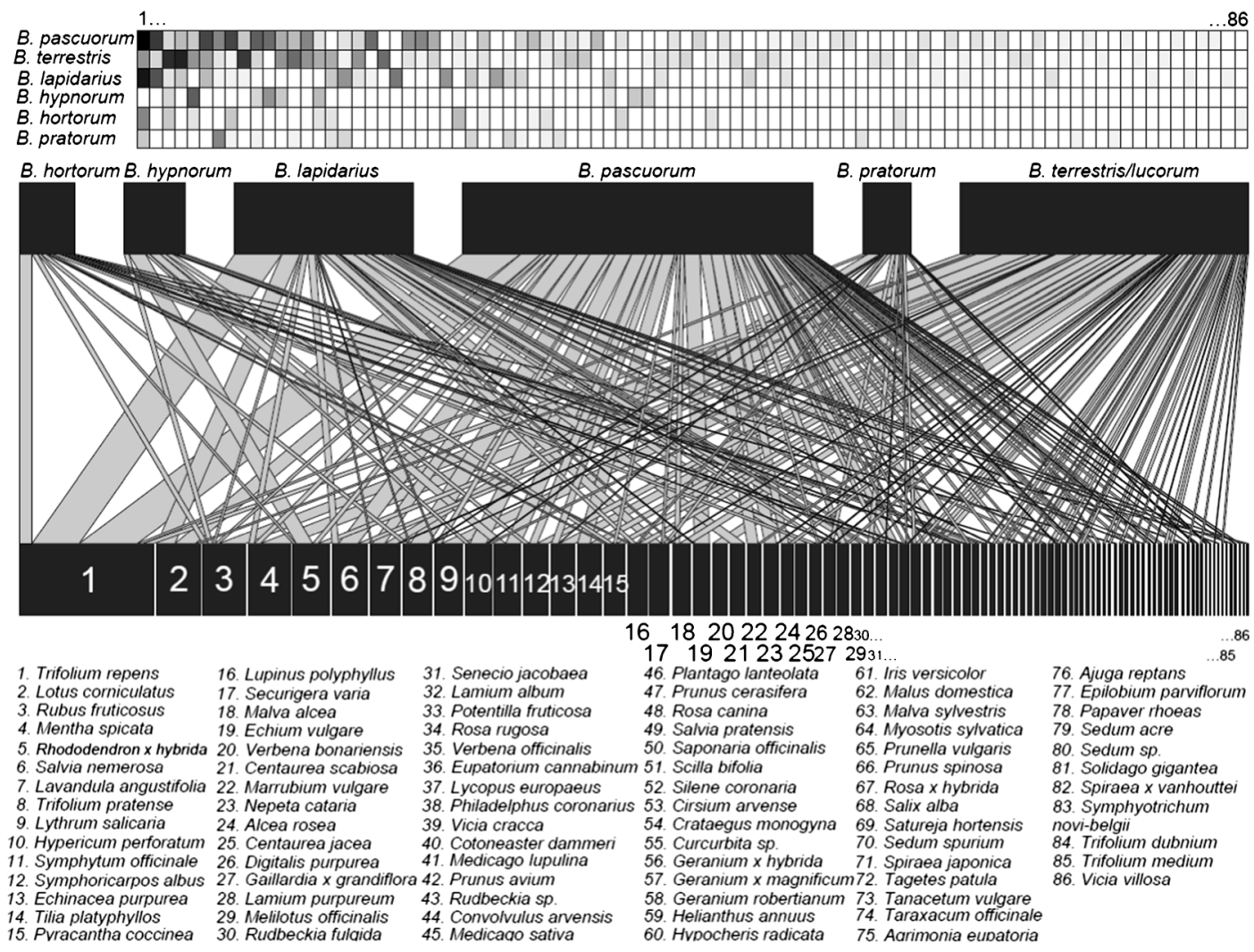

Figure 2. Bumble bee-flowering plant visitation networks. Level of shading of matrix entries in top network positively correlates with number of observations. Below Lines between a bumble bee and plant species show the plant species visited by that species group; line width correlates with the number of visits recorded for this particular plant species; bar width correlates with the number of individuals recorded per species group in relation to all individuals recorded (top), or with the proportion of visits to each plant species in relation to the overall number of visits (bottom), respectively.

Table I. Model results for abundance, species richness, and individual species.

\begin{tabular}{lllllll}
\hline Species & Model & $\log (L)$ & $K$ & AICc & Wi & AICc null model \\
\hline Abundance & $D+B+V+H$ & -1610 & 8 & 7842 & 1 & 3349 \\
Species richness & $D+B+V+H$ & -3913 & 8 & 3630 & 1 & 753 \\
B. terrestis & $D+B+V+H$ & -296 & 8 & 608 & 1 & 37 \\
B. lapidarius & $D+B+V+H$ & -385 & 8 & 787 & 1 & 196 \\
B. hortorum & $D+B+V+H$ & -243 & 8 & 502 & 1 & 361 \\
B. pratorum & $D+B+V+H$ & -115 & 8 & 246 & 1 & 646 \\
B. pascuorum & $V+H$ & -358 & 6 & 729 & 1 & 37
\end{tabular}

Model summary: $\log (L)$ the maximized log-likelihood, $K$ number of estimated parameters, $A I C c$ Akaike's information criterion corrected for small sample bias, Wi Akaike weights, AICc null model difference in AICc compared with the null model, $D$ plant diversity, $B$ blooming product, $V$ vegetation community pattern, $H$ habitat parameters 
Table II. Model coefficients (and standard errors) of the environmental variables included in the best ranked models in Poisson/binomial GLMMs.

\begin{tabular}{lllllll}
\hline Species & Model & Intercept & $\begin{array}{l}\text { Plant } \\
\text { diversity }\end{array}$ & $\begin{array}{l}\text { Blooming } \\
\text { product }\end{array}$ & Plant community & Habitat \\
\hline Abundance & $D+B+V+H$ & $0.36 \pm 0.08$ & $0.29 \pm 0.03$ & $0.02 \pm 0.02$ & $-0.83 \pm 0.06$ & $-0.13 \pm 0.07$ \\
Diversity & $D+B+V+H$ & $1.21 \pm 0.21$ & $0.15 \pm 0.01$ & $0.05 \pm 0.01$ & $-1.74 \pm 0.04$ & $-0.17 \pm 0.20$ \\
B. terrestis & $D+B+V+H$ & $4.29 \pm 1.48$ & $2.01 \pm 0.43$ & $-0.10 \pm 0.11$ & $-1.44 \pm 0.37$ & $-1.05 \pm 1.48$ \\
B. lapidarius & $D+B+V+H$ & $0.36 \pm 0.56$ & $1.38 \pm 0.18$ & $0.13 \pm 0.10$ & $-3.11 \pm 0.36$ & $-0.71 \pm 0.52$ \\
B. hortorum & $D+B+V+H$ & $-13.41 \pm 2.74$ & $2.95 \pm 0.40$ & $0.41 \pm 0.14$ & $-9.17 \pm 0.95$ & $-2.57 \pm 2.74$ \\
B. pratorum & $D+B+V+H$ & $-1.75 \pm 4.82$ & $4.56 \pm 0.85$ & $-0.09 \pm 0.26$ & $-18.8 \pm 1.90$ & $12.7 \pm 5.35$ \\
& & & -1.98 & $-0.44 \pm 0.49$ & & \\
$0.23 \pm 0.58$ & & & \pm 0.32 & & & \\
& & & & & & \\
\hline
\end{tabular}

$D$ plant diversity, $B$ blooming product, $V$ vegetation community pattern, $H$ habitat parameters

cultivated by (semi-)professional gardeners and offered a comparatively high plant species richness over the entire survey period (see Tables SI and SII). Especially the Kurpark and Pferdeteich were further surrounded by additional gardens (see Table SI), which are known to attract and support insects (Samnegård et al. 2011). Another reason for the high abundance of bumble bees at these sites could be the comparatively high abundance of Fabaceae and Lamiaceae (see Tables SI and SII), which are known to be preferentially visited by bumble bees (Goulson et al. 2008a; Sikora and Kelm 2012).

We also found high numbers of bumble bees on study plots in the city center of Lüneburg, e.g., $15 \mathrm{~B}$. terrestris and $12 \mathrm{~B}$. pascuorum in the Rathaus garden (with $65 \%$ of concrete in the surrounding) at 1 day in August, demonstrating that bumble bees are able to forage even at very isolated patches in the city center,

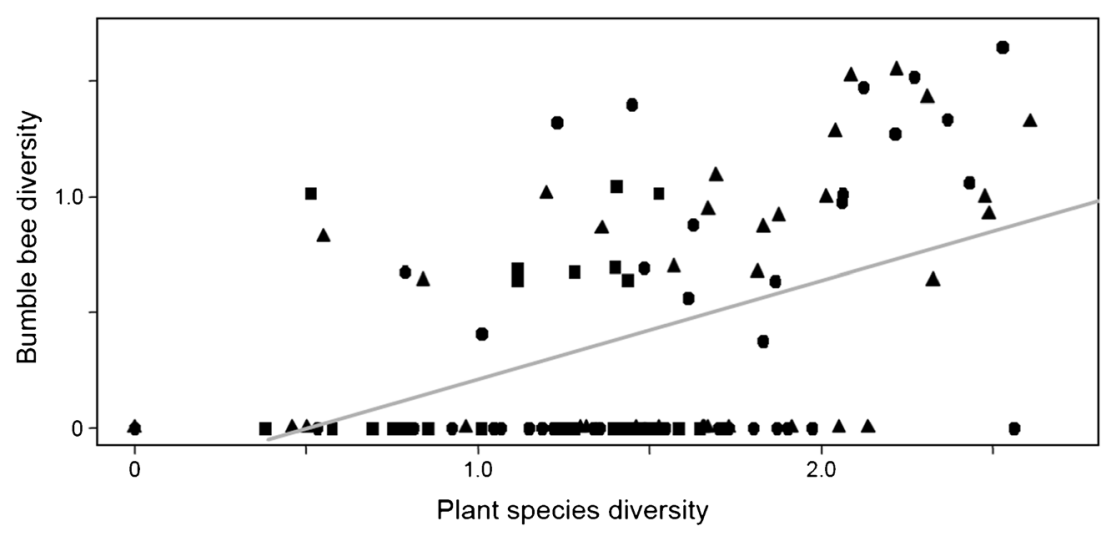

Figure 3. Correlation between bumble bee and plant species Shannon diversity in relation to the distance from the city central point. Different symbols indicate different urbanization categories: squares mark study plots in the city center, circles plots in the urban area and triangles plots in the suburban area. Each symbol represents one survey; we refrained from labeling individual months because month had low explanatory power if included as a random intercept in a mixed effect model (data not shown). 
provided these patches comprise sufficient floral resources. This primarily applies to permanently cultivated gardens, which may explain why several studies consider gardens in cities "harbors or islands" for bumble bees and other insects (Ahrné et al. 2009; Samnegård et al. 2011; Goulson et al. 2012; Pereira-Peixoto et al. 2014).

Consequently, the availability and diversity of attractive plant species represents a prerequisite for the presence of bumble bee foragers in the city center. Our finding agrees with Jha and Kremen (2013a) who also found that foraging ranges in the North American native bumble bee Bombus vosnesenskii Radoszkowski were primarily driven by floral resource diversity in a heterogeneous landscape. Likewise, multiple studies found that the abundance of several bumble bee species was positively correlated with high flowering plant diversity as well as with the presence of particular plants families (Williams 1986; Mänd et al. 2002; Goulson and Hanley 2004; Hines and Hendrix 2005), further stressing the importance of plant diversity and community composition. Interestingly, however, close to $30 \%$ of the bumble bees foraged on only six plant species: T. repens (Fabaceae), Lotus corniculatus L. (Fabaceae), Rubus fruticosus (Rosaceae), Mentha spicata L. (Lamiaceae), Rhododendron $\times$ hybrida (Ericaceae), and Salvia nemorosa L. (Lamiaceae). Five of these plants belonged to the most visited plant families: Fabaceae, Lamiaceae, and Rosaceae. Most bumble bees $(27.2 \%)$ were recorded on Fabaceae, whereas other plant families, such as Hydrangeaceae Dumort. (five recorded visits) or Iridaceae Juss. (two), were hardly visited by any bumble bees. This differential visitation pattern cannot be explained by availability alone, as indicated by the comparatively weak effect of the blooming product, which is correlated with plant abundance at our sites. Moreover, even the very abundant plant family Asteraceae, with more than 250 individual plant recordings in this study, was only visited by $76(11 \%)$ bumble bees. In contrast, we only recorded 130 Fabaceae plants.

The strong preference of bumble bees for Fabaceae also agrees with results from previous studies (Goulson and Darvill 2004; Goulson et al.
2005, 2008a; Connop et al. 2010; Redpath et al. 2010). Fabaceae seem thus to be highly important for bumble bees, especially for longer-tongued species, such as B. hortorum (19 visits to Fabaceae in this study, $47.5 \%)$, B. lapidarius (68 visits, $52.3 \%$ ), and B. pascuorum (76 visits, $32.2 \%$ ). A potential explanation for their importance may be that Fabaceae pollen is richer in protein compared to pollen of other plant families, as suggested by Goulson et al. (2005) and Hanley et al. (2008). The differential importance of different plant families/species can thus likely be explained by differences in the plants' nectar or pollen quality, as bumble bees appear to require pollen of high protein content (Leonhardt and Blüthgen 2012), which was found to increase their survival and immunocompetence (Genissel et al. 2002; Tasei and Aupinel 2008; Brunner et al. 2014). Interestingly, most of the plants visited by bumble bees in this study were native plants, such as $T$. repens, $R$. fruticosus, or L. corniculatus (Table SII). This finding agrees with recent studies that suggest native plant species to promote bee abundance in urban gardens (Pawelek et al. 2009; Pardee and Philpott 2014).

Most bumble bees species observed in this study are ubiquitous (von Hagen et al. 2003) and generalized foragers. For example, the second most common species group B. terrestris/ lucorum (208 individuals recorded) was observed on 19 different plant families. The most abundant bumble bee species, B. pascuorum, also foraged on 14 different plant families. Despite their generalized foraging behavior, the degree of specialization of the urban bumble bee-plant network was slightly higher than in (semi-)natural areas (Fründ et al. 2010). This finding is even more surprising as we may have grouped several species, which may visit different plant species, into one group, thereby increasing the number of flowering plant species per group. Grouping species should generate a more generalized network (i.e., lower $\mathrm{H}_{2}{ }^{\prime}$ value) than would be observed for the actual species. The higher degree of specialization as found for our bee group-plant network indicates that bumble bees tend to more strongly partition floral resources among each other in 
urban compared to (semi-)natural landscapes. This behavior might be explained by a generally higher plant diversity in cities compared to the seminatural, often human-influenced landscapes of industrialized countries (Thompson et al. 2003; Gaston et al. 2005b; Loram et al. 2008), which may allow different bumble bee species to more easily distribute themselves across different plant species (see also Miller-Struttmann and Galen 2014) and, in doing so, avoid competition. However, more comparative network analyses are needed in order to confirm this hypothesis.

Note that all bumble bees observed in our study belong to species commonly found in and outside of cities (Goulson et al. 2005, 2008a; Banaszak-Cibicka and Żmihorski 2012), while typically rare species, such as $B$. sylvarum L. or B. humilis Illiger, were not observed in our study. Consequently, there are most likely "winners and losers" of urbanization (Banaszak-Cibicka and Żmihorski 2012). With regard to bumble bees, winners comprise, e.g., the shorttongued $B$. terrestis and the medium longtongued B. pascuorum (Banaszak-Cibicka and Żmihorski 2012). This finding agrees with Goulson et al. (2005) who suggested that mostly short-tongued species persist in altered areas due to their generally less specialized diet. However, species richness may have been underestimated in this study, as individuals were categorized into groups, potentially overlooking rare, similar looking species.

To conclude, plant species diversity and composition are the most important factors determining bumble bee abundance and diversity in (and outside of) small cities, and specific plant species and families (e.g., Fabaceae) play a disproportionally important role. In particular flower-rich parks and gardens can offer a continuous food supply attracting bumble bees even to isolated patches in the city center provided they comprise a specific composition (e.g., Fabaceae and Lamiaceae) of plant species. Although our findings do not necessarily apply to larger cities, such floral resource patches can consequently compensate the negative effect of urbanization for this group of pollinators, at least in small cities.

\section{ACKNOWLEDGMENTS}

We thank Peter Zurheide, head of „Grünplanung, Friedhöfe und Forsten“, Susanne Schröder (Dipl.-Ing. (FH) Landespflege) and Oliver-Martin Freese, gardener (Gärtnermeister) from the city of Lüneburg and the Kleingärtner Bezirksverband Lüneburg for permission to survey bumble bees in parks, gardens, and on meadows, and Johann Neumayer as well as Rolf Witt for help with the identification of some bumble bee specimens. We also thank Dr. Wilhelm Hülsmann for technical support and two anonymous reviewers for their helpful comments on a previous version of the manuscript. Funding for SDL was provided by the Deutsche Forschungs-Gemeinschaft (DFG project: LE 2750/1-1).

La diversité et la composition des plantes compensent les effets négatifs de l'urbanisation pour l'approvisionnement des bourdons

déclin des abeilles / fragmentation de l'habitat / Hymenoptera / pollinisation / paysage urbain

Diversität und Zusammensetzung von Pflanzengemeinschaften kompensieren negative Auswirkungen der Urbanisierung für sammelnde Hummeln

Bienenrückgang / Habitatfragmentierung / Hymenoptera / Bestäubung / urbaner Lebensraum

\section{REFERENCES}

Ahrné, K., Bengtsson, J., Elmqvist, T., Somers, M. (2009) Bumble bees (Bombus spp) along a gradient of increasing urbanization. PLoS One 4, e5574

Antrop, M. (2004) Landscape change and the urbanization process in Europe. Landsc. Urban Plan. 67, 9-26

Aronson, M.F.J., La Sorte, F.A., Nilon, C.H., Katti, M., Goddard, M.A., et al. (2014) A global analysis of the impacts of urbanization on bird and plant diversity reveals key anthropogenic drivers. Proc. R. Soc. B Biol. Sci. 281, 20133330

Banaszak-Cibicka, W., Żmihorski, M. (2012) Wild bees along an urban gradient: winners and losers. J. Insect Conserv. 16, 331-343 
Bates, A.J., Sadler, J.P., Fairbrass, A.J., Falk, S.J., Hale, J.D., Matthews, T.J., Stout, J.C. (2011) Changing bee and hoverfly pollinator assemblages along an urbanrural gradient. PLoS One 6, e23459

Blüthgen, N., Menzel, F., Blüthgen, N. (2006) Measuring specialization in species interaction networks. BMC Ecol. 6, 9. doi:10.1186/1472-6785-6-9

Bommarco, R., Biesmeijer, J.C., Meyer, B., Potts, S.G., Poyry, J., Roberts, S.P.M., Steffan-Dewenter, I., Ockinger, E. (2010) Dispersal capacity and diet breadth modify the response of wild bees to habitat loss. Proc. R. Soc. B Biol. Sci. 277, 2075-2082

Braun-Blanquet, J. (1994) Pflanzensoziologische Grundzüge der Vegetationskunde. Springer Verlag, Wien

Brunner, F.S., Schmid-Hempel, P., Barribeau, S.M. (2014) Protein-poor diet reduces host-specific immune gene expression in Bombus terrestris. Proc. R. Soc. B Biol. Sci. 281, 20140128

Connop, S., Hill, T., Steer, J., Shaw, P. (2010) The role of dietary breadth in national bumblebee (Bombus) declines: simple correlation? Biol. Conserv. 143, 27392746

Edwards, M., Jenner, M. (2009) Field Guide to the Bumblebees of Great Britain and Ireland. Rev. Ocelli, Great Britain

Eremeeva, N.I., Sushchev, D.V. (2005) Structural changes in the fauna of pollinating insects in urban landscapes. Russ. J. Ecol. 36, 259-265

Fischer, J., Lindenmayer, D.B. (2007) Landscape modification and habitat fragmentation: a synthesis. Glob. Ecol. Biogeogr. 16, 265-280

Fitzpatrick, Ú., Murray, T.E., Paxton, R.J., Breen, J., Cotton, D., Santorum, V., Brown, M.J. (2007) Rarity and decline in bumblebees - a test of causes and correlates in the Irish fauna. Biol. Conserv. 136, 185-194

Fründ, J., Linsenmair, K.E., Blüthgen, N. (2010) Pollinator diversity and specialization in relation to flower diversity. Oikos 119, 1581-1590

Fussell, M., Corbet, S.A. (1992) Flower usage by bumblebees: a basis for forage plant management. J. Appl. Ecol. 29, 451

Gallai, N., Salles, J.-M., Settele, J., Vaissière, B.E. (2009) Economic valuation of the vulnerability of world agriculture confronted with pollinator decline. Ecol. Econ. 68, 810-821

Garbuzov, M., Ratnieks, F.L.W., Thompson, K. (2013) Quantifying variation among garden plants in attractiveness to bees and other flower-visiting insects. Funct. Ecol. 28, 364-378

Gaston, K.J., Smith, R.M., Thompson, K., Warren, P.H. (2005a) Urban domestic gardens (II): experimental tests of methods for increasing biodiversity. Biodivers. Conserv. 14, 395-413

Gaston, K.J., Warren, P.H., Thompson, K., Smith, R.M. (2005b) Urban domestic gardens (IV): the extent of the resource and its associated features. Biodivers. Conserv. 14, 3327-3349
Genissel, A., Aupinel, P., Bressac, C., Tasei, J.-N., Chevrier, C. (2002) Influence of pollen origin on performance of Bombus terrestris micro-colonies. Entomol. Exp. Appl. 104, 329-336

Geslin, B., Gauzens, B., Thébault, E., Dajoz, I., Ollerton, J. (2013) Plant pollinator networks along a gradient of urbanisation. PLoS One 8, e63421

Goulson, D. (2010) Bumblebees. Behaviour, ecology, and conservation. Oxford University Press, Oxford

Goulson, D., Darvill, B. (2004) Niche overlap and diet breadth in bumblebees: are rare species more specialized in their choice of flowers? Apidologie 35, 55-63

Goulson, D., Hanley, M. (2004) Distribution and forage use of exotic bumblebees in South Island, New Zealand. N. Z. J. Ecol. 28, 225-232

Goulson, D., Hanley, M., Darvill, B., Ellis, J., Knight, M. (2005) Causes of rarity in bumblebees. Biol. Conserv. $122,1-8$

Goulson, D., Lye, G.C., Darvill, B. (2008a) Diet breadth, coexistence and rarity in bumblebees. Biodivers. Conserv. 17, 3269-3288

Goulson, D., Lye, G.C., Darvill, B. (2008b) Decline and conservation of bumblebees. Annu. Rev. Entomol. 53, 191-208

Goulson, D., Whitehorn, P., Fowley, M. (2012) Influence of urbanisation on the prevalence of protozoan parasites of bumblebees. Ecol. Entomol. 37, 83-89

Hagen, E. von, Aichhorn, A., Fadini, A. (2003) Hummeln. Bestimmen, ansiedeln, vermehren, schützen; Angaben über die nur in den Alpen vorkommenden Hummelarten von Ambros Aichhorn, Goldegg; Bestimmungsschlüssel für lebende Tiere und nach Farben. Fauna-Verl., Nottuln

Hanley, M.E., Franco, M., Pichon, S., Darvill, B., Goulson, D. (2008) Breeding system, pollinator choice and variation in pollen quality in British herbaceous plants. Funct. Ecol. 22, 592-598

Hegi, G., Conert, H.J., Scholz, H. (1995) Illustrierte Flora von Mittel-Europa. Weißdorn-Verlag, Jena

Heinrich, B. (1976) The foraging specialisations of individual bumblebees. Ecol. Monogr. 46, 105

Heinrich, B., Mudge, P.R., Deringis, P.G. (1977) Laboratory analysis of flower constancy in foraging bumblebees: Bombus ternarius and B. terricola. Behav. Ecol. Sociobiol. 2, 247-265

Hines, H.M., Hendrix, S.D. (2005) Bumble bee (Hymenoptera: Apidae) diversity and abundance in tallgrass prairie patches: effects of local and landscape floral resources. Environ. Entomol. 34, 1477-1484

Jäger, E.J. (2011) Rothmaler-Exkursionsflora von Deutschland. Gefäßpflanzen: Grundband. Spektrum Akademischer Verlag, Heidelberg

Jha, S., Kremen, C. (2013a) Resource diversity and landscape-level homogeneity drive native bee foraging. Proc. Natl. Acad. Sci. 110, 555-558

Jha, S., Kremen, C. (2013b) Urban land use limits regional bumble bee gene flow. Mol. Ecol. 22 , 2483-2495 
Kearns, C.A., Oliveras, D.M. (2009) Environmental factors affecting bee diversity in urban and remote grassland plots in Boulder, Colorado. J. Insect Conserv. 13, 655-665

Kleijn, D., Raemakers, I. (2008) A retrospective analysis of pollen host plant use by stable and declining bumble bee species. Ecology 89, 1811-1823

Leonhardt, S.D., Blüthgen, N. (2012) The same, but different: pollen foraging in honeybee and bumblebee colonies. Apidologie 43, 449-464

Leonhardt, S.D., Gallai, N., Garibaldi, L.A., Kuhlmann, M., Klein, A.M. (2013) Economic gain, stability of pollination and bee diversity decrease from southern to northern Europe. Basic Appl. Ecol. 14, 461-471

Loram, A., Thompson, K., Warren, P.H., Gaston, K.J. (2008) Urban domestic gardens (XII): the richness and composition of the flora in five UK cities. J. Veg. Sci. 19, 321-330

Lye, G.C., Osborne, J.L., Park, K.J., Goulson, D. (2012) Using citizen science to monitor Bombus populations in the UK: nesting ecology and relative abundance in the urban environment. J. Insect Conserv. 16, 697-707

Mänd, M., Mänd, R., Williams, I. (2002) Bumblebees in the agricultural landscape of Estonia. Agric. Ecosyst. Environ. 89, 69-76

Martins, A.C., Gonçalves, R.B., Melo, G.A.R. (2013) Changes in wild bee fauna of a grassland in Brazil reveal negative effects associated with growing urbanization during the last 40 years. Zoologia (Curitiba) 30, 157-176

Matteson, K.C., Ascher, J.S., Langellotto, G.A. (2008) Bee richness and abundance in New York City urban gardens. Ann. Entomol. Soc. Am. 101, 140-150

Miller-Struttmann, N.E., Galen, C. (2014) High-altitude multi-taskers: bumble bee food plant use broadens along an altitudinal productivity gradient. Oecologia 176, 1033-1044

Nielsen, C., Heimes, C., Kollmann, J. (2008) Little evidence for negative effects of an invasive alien plant on pollinator services. Biol. Invasions 10, 1353-1363

Paker, Y., Yom-Tov, Y., Alon-Mozes, T., Barnea, A. (2014) The effect of plant richness and urban garden structure on bird species richness, diversity and community structure. Landsc. Urban Plan. 122, 186-195

Pardee, G.L., Philpott, S.M. (2014) Native plants are the bee's knees: local and landscape predictors of bee richness and abundance in backyard gardens. Urban Ecosyst. 17, 641-659
Pawelek, J.C., Frankie, G.W., Thorp, R.W., Przybylski, M. (2009) Modification of a community garden to attract native bee pollinators in urban San Luis Obispo, California. Cities Environ. 2, 1-20

Pellissier, V., Maurel, N., Machon, N. (2013) Multi-scale assessment of pollination of Lotus corniculatus (L.) in a peri-urban fringe. Plant Ecol Divers 6, 195-203

Pereira-Peixoto, M., Pufal, G., Feitosa Martins, C., Klein, A.M. (2014) Spillover of trap-nesting bees and wasps in an urban-rural interface. J. Insect Conserv. 18, 815825

Prŷs-Jones, O.E., Corbet, S.A. (2011) Bumblebees. Pelagic Publishing, Exeter

Redpath, N., Osgathorpe, L.M., Park, K., Goulson, D. (2010) Crofting and bumblebee conservation: the impact of land management practices on bumblebee populations in northwest Scotland. Biol. Conserv. 143, 492-500

Samnegård, U., Persson, A.S., Smith, H.G. (2011) Gardens benefit bees and enhance pollination in intensively managed farmland. Biol. Conserv. 144, 2602-2606

Schmeil, O., Fitschen, J. (2011) Die Flora Deutschlands und der angrenzenden Länder. Ein Buch zum Bestimmen aller wildwachsenden und häufig kultivierten Gefäßpflanzen. Quelle und Meyer, Wiebelsheim

Sikora, A., Kelm, M. (2012) Flower preferences of the Wroclaw botanical garden (Bombus spp.). J. Apic. Sci. 56, 27-36

Tasei, J.-N., Aupinel, P. (2008) Nutritive value of 15 single pollens and pollen mixes tested on larvae produced by bumblebee workers (Bombus terrestris, Hymenoptera: Apidae). Apidologie 39, 397-409

Thompson, K., Austin, K.C., Smith, R.M., Warren, P.H., Angold, P.G., Gaston, K.J. (2003) Urban domestic gardens (I): putting small-scale plant diversity in context. J. Veg. Sci. 14, 71-78

Tommasi, D., Miro, A., Higo, H.A., Winston, M.L. (2004) Bee diversity and abundance in an urban setting. Can. Entomol. 136, 851-869

Williams, P.H. (1986) Environmental change and the distributions of British bumble bees (Bombus Latr). Bee World 50-61

Williams, N.M., Winfree, R. (2013) Local habitat characteristics but not landscape urbanization drive pollinator visitation and native plant pollination in forest remnants. Biol. Conserv. 160, 10-18 